\title{
BREAKING WITH THE PAST
}

The Kuomintang Central Reform Committee on Taiwan, 1950-52

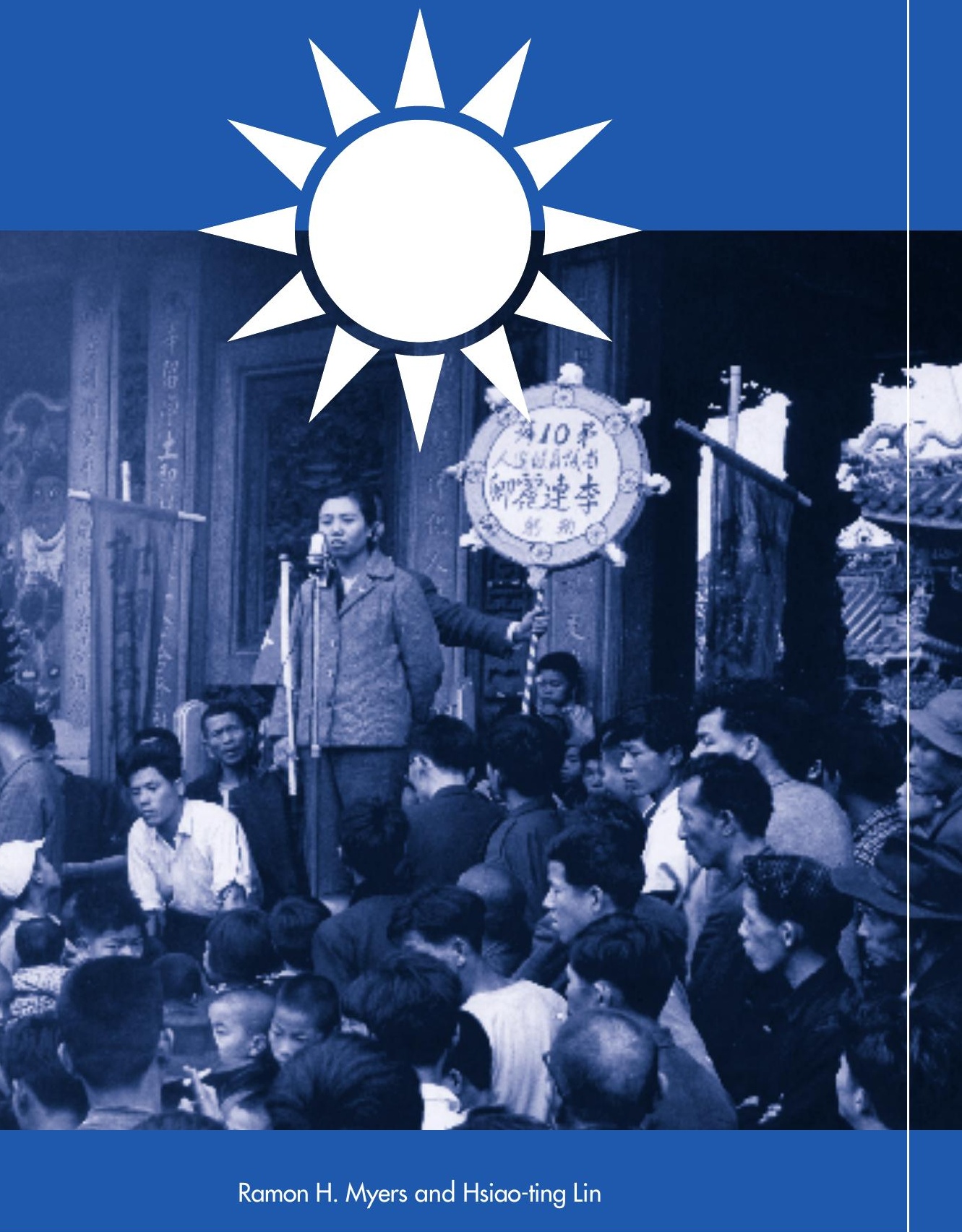




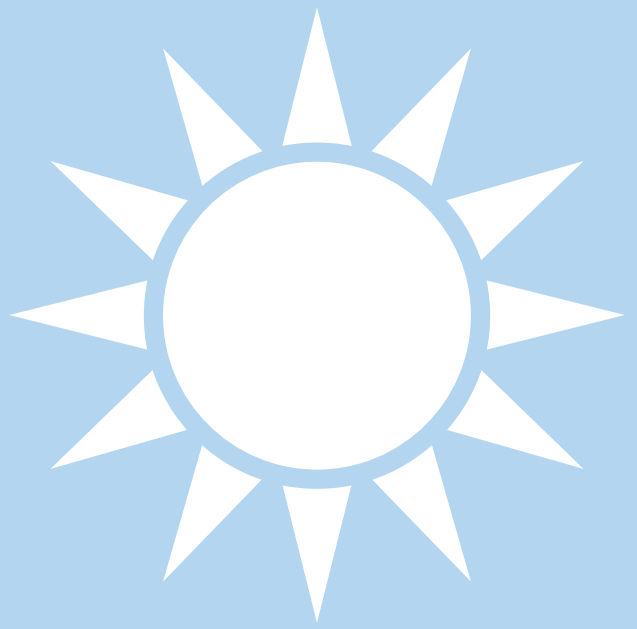




\title{
BREAKING WITH THE PAST \\ The Kuomintang Central Reform \\ Committee on Taiwan, 1950-52
}

\author{
Ramon H. Myers \\ Senior Fellow, Hoover Institution \\ Hsiao-ting Lin \\ Visiting Fellow, Hoover Institution
}

HOOVER INSTITUTION PRESS

Stanford University Stanford, California 
The Hoover Institution on War, Revolution and Peace, founded at Stanford University in 1919 by Herbert Hoover, who went on to become the thirty-first president of the United States, is an interdisciplinary research center for advanced study on domestic and international affairs. The views expressed in its publications are entirely those of the authors and do not necessarily reflect the views of the staff, officers, or Board of Overseers of the Hoover Institution.

www.hoover.org

Hoover Institution Press Publication

Copyright (c) 2007 by the Board of Trustees of the Leland Stanford Junior University

Photos from the Modern China Archives and Special Collections, Hoover Institution Archives, Stanford University.

All rights reserved. No part of this publication may be reproduced, stored in a retrieval system, or transmitted in any form or by any means, electronic, mechanical, photocopying, recording, or otherwise, without written permission of the publisher.

First printing, 2007

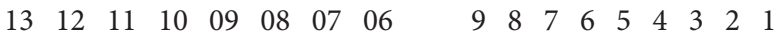

Manufactured in the United States of America

Design by Tobi Designs 


\section{Contents}

About the Authors iv

Foreword by Ramon H. Myers $\quad$ v

Introduction 1

Reinventing a New Political Party 2

Building a Strong Party and Leadership $\quad 6$

Expanding the Party's Social Foundation $\quad 8$

Local-level Political Reforms $\quad 13$

Promoting a Grand Vision:

Toward a Prosperous Economy with Equity 17

Concluding Remarks $\quad 21$ 


\section{About the Authors}

RAMON H. MYERS is a senior fellow at the Hoover Institution, Stanford University. He is the coauthor, with Linda Chao, of The First Chinese Democracy: Political Life in the Republic of China on Taiwan and has written numerous articles about Taiwan's political and economic history. His most recent work, with Jialin Zhang, is The Struggle Across the Taiwan Strait: The Divided China Problem published by Hoover Institution Press in 2006.

HSIAO-TING LIN is a visiting fellow at the Hoover Institution who received his D.Phil. from Oxford University in 2003. He is the author of Tibet and Nationalist China's Frontier: Intrigues and Ethnopolitics, 1928-49, T. V. Soong in Modern Chinese History: A Look at His Role in Sino-American Relations in World War II (with Tai-chun Kuo), and more than 30 essays, journal articles and book reviews. His academic interests include ethnopolitics in greater China, the political history of modern China, and the Kuomintang (the Nationalist Party) in post-1949 Taiwan. 


\section{Foreword}

In March 2005 the Hoover Institution Archives announced a new initiative, the Modern China Archives and Special Collections, which includes archival and other special materials concerning the Republic of China from 1911 to 1949, Taiwan from 1949 to the present, and the evolution of mainland China from 1949 to the present.

The Hoover Institution undertook this initiative because, for many decades, its archives has collected and preserved a rich collection of Chinese, Japanese, and Western documents-including the private papers of individuals as well as the personal documents and official records of leaders and statesmen, government officials, missionaries, and engineers-related to the above periods. In 2003 some of the rare materials describing the rise of the Communist and Nationalist Parties in mainland China and the rise of an opposition party in Taiwan were transferred from the Hoover Institution's former East Asian Collection to the Hoover Institution Archives. Few, if any, copies of those materials exist in the public domain. Those materials have now been accessioned, placed on the Hoover website, and preserved for researchers to use in the Hoover Institution Archives.

In April 2004, the Hoover Institution opened the restricted nineteen boxes (from the original fifty-nine boxes received in 1976) of the personal papers of 
T. V. Soong, a leading official in the Nationalist government from the late 1920s to 1949 , along with two thousand documents donated by the Soong family. At the same time the Hoover Institution and the Kuomintang (Nationalist Party) agreed to preserve those records and make them available for researchers. By late 2007, more than 900,000 microfilm frames of Kuomintang documents had been completed. In late 2005 Chiang Kai-shek's family placed, on deposit, his diaries and those of his son Chiang Ching-kuo in the Hoover Archives. Hoover archivists have opened the Chiang Kai-shek diaries from 1917 to 1945 to readers. In August 2006, K'ung Hsiang-hsi family members donated his papers to the Hoover Institution.

To encourage researchers to use these new materials, we have established a new essay series of which this is the third monograph (the first is The Modern China Archives and Special Collections, and the second is T.V. Soong in Modern Chinese History). The series introduces new documents from our collections and suggests interpretations of events that may differ from those advanced earlier, especially as they relate to major turning points and significant historical changes in China's recent history. (The essays reflect only the opinions of the authors.) The essays also identify and discuss special materials that users might find of interest and assistance and provide an impetus for researchers to consult the Hoover Institution's expanding Chinese archives and special collections.

Ramon H. Myers

Senior Fellow, Hoover Institution 


\section{Introduction}

FEW DEFEATED POLITICAL PARTIES in wartime have the opportunity to make a fresh start in a new location. Even fewer can leave their failures behind and go on to succeed. The Chinese Nationalist Party (Kuomintang, KMT) was such an exception. In late 1949, having been almost destroyed by the Chinese Communists, the KMT relocated to Taiwan and reinvented itself. Not only did the KMT leadership build a new party that has endured for five decades, but it built a new polity on Taiwan that created economic prosperity and China's first democracy.

How did this defeated party reinvent itself? New microfilmed materials on the KMT Central Reform Committee-now in the Hoover Institution Archives at Stanford University-shed new light on this unusual phenomenon. From August 1950 to October 1952, more than four hundred working meetings were held almost four times a week to discuss how to build a new political party and implement Nationalist government policies.

Chiang Kai-shek began the reforms by establishing the Central Reform Committee (CRC) to replace the inept Central Standing Committee and Central Executive Committee, the party's two most powerful agencies on the mainland. Unlike its predecessors, the CRC recruited young, highly educated party members, who, encouraged by Chiang Kai-shek, revitalized the KMT by introducing new institutions that would build a society based on the principles of Sun Yat-sen, one of the party's founders. 


\section{Reinventing a New Political Party}

IN MID-1945, PARTY FACTIONAL STRUGGLES, corruption, and low morale were on the increase within the KMT. The Central Club faction (C.C. clique), headed by the Chen brothers (Guofu and Lifu) had become so powerful that it threatened to divide the Nationalist government, pitting the KMT party against the government bureaucracy and the military. ${ }^{1}$ Support for the KMT was on the decline, and KMT leaders were unable to mobilize either citizens or soldiers to support the party. Chiang tried but failed to strengthen the KMT with the backing of the Three Principles of the People Youth Corps, a powerful organization then dominated by the Chen brothers' Central Club. ${ }^{2}$

In the summer of 1947, Chiang still hoped to reform the KMT, but he had no support. Moreover, remnants of the party and state were now confronted by the communist insurgency, the military forces of which had expanded and become stronger, in contrast to those of the Nationalist government, which had become corrupt and lacking in legitimate authority.

Writing in his diary in January 1949, after retiring from the presidency of the Republic of China, Chiang Kai-shek wrote:

The biggest reason for our defeat was that we never have been able to establish a new, solid organizational system. The old one had long deteriorated and collapsed. In the current, crucial phase between the old and the new, we have lost the basic means to rebuild and save our country. This is why we have been defeated. ${ }^{3}$

In early 1949, President Chiang stepped down when military support for his party and government collapsed. Vice President Li Zongren succeeded him but presided over a defeated Nationalist regime. Chiang, who retained his positions as KMT chairman and commander in chief of the Nationalist armed force, still believed he could launch party reform. On July 18, 1949, Chiang revealed his plan to the remaining Central Standing Committee members, who had

\footnotetext{
1 See: Bruce J. Dickson, "The Lessons of Defeat: The Reorganization of the Kuomintang on Taiwan, 1950-52," China Quarterly, no. 133 (1993): 58-59; Xu Fuming, Zhongguo Guomindang de Gaizao, 1950-1952 (The reform of the KMT, 1950-1952) (Taipei: Zhengzhong Shuju, 1986), pp. 45-53.

${ }^{2}$ Hoover Institution Archives, KMT Central Reform Committee Archive (hereafter, CRCA), 6.4-2, reel 1, Chiang Kai-shek's introduction to Resolution on the Reforming of our Party, July 18, 1950.

${ }^{3}$ Qin Xiaoyi ed., Zhongtong Jianggong Dashi Changbian Chugao (The preliminary draft of collected materials describing the activities of President Chiang Kai-shek) (Hereafter Dashi Changbian), vol. 7, part 2 (Taipei, 1978), p. 241.
} 
gathered in Canton. ${ }^{4}$ They agreed to review Chiang's plan but did not believe it would work. In despair, Chiang then flew to Sichuan to persuade party, military, and government officials in China's southwestern provinces to keep on fighting the Communists. There was no determination in their hearts to resist the communist advance. Chiang now realized that Taiwan was his last hope; with his son, Chiang Ching-kuo, he flew to Taipei in December 1949, never to set foot on the Chinese mainland again. ${ }^{5}$

In the early months of 1950, Chiang and his military officers tried to build fortifications along Taiwan's western coast. Defeat seemed inevitable. Chiang's military intelligence revealed that communist forces were assembling a huge flotilla from Zhejiang, Fujian, and Guangdong provinces with which to attack Taiwan. Chiang ordered the complete withdrawal to Taiwan of all Nationalist forces still in Hainan, Choushan, and other offshore islands along the southeastern China coast. At the same time, Chiang begged for U.S. support for his final struggle against communism. Washington did not reply.

In the meantime, Chiang Kai-shek still hoped for party reform. In early January 1950, he formed a study group to draft a plan. Writing in his diary on January 3, Chiang specified that, to attract superior members, "the reform time table should stress the importance of the party being a new organization,

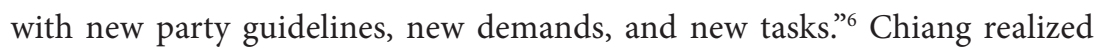
that reform could only succeed by building a new party and eliminating party factionalism. That meant rejecting the uncooperative party veterans and KMT clique members. ${ }^{7}$

But serious and terrifying conditions now threatened Taiwan and needed Chiang's attention. Intense arguments and bitter recriminations within the party and government had erupted. Chiang's leading officials quarreled among themselves and with Chiang. From February to July 1950, many feared the KMT would split before the Communists even invaded Taiwan. ${ }^{8}$ Such defeatist views infuriated Chiang and his closest associates, and he despised the ongoing factional rivalries within the Nationalist government. In March 1950,

\footnotetext{
${ }^{4}$ Ibid., p. 331; KMT Central Reform Committee, Dangwu Baogao (Report on party affairs), vol. 1 (Taipei, 1952), p. 13.

${ }^{5}$ Linda Chao and Ramon H. Myers, The First Chinese Democracy: Political Life in the Republic of China on Taiwan (Baltimore: The Johns Hopkins University Press, 1998), pp. 23-24.

${ }^{6}$ Dashi Changbian, vol. 9, pp. 6-7.

${ }^{7}$ Ibid., pp. 2-6.

${ }^{8}$ Ibid., pp. 60, 65-66.
} 
having argued with Premier Chen Cheng over who should control party and state financial affairs, Taiwan governor K.C. Wu threatened to resign. ${ }^{9}$ Rivalry between the Legislative Yuan and the Executive Yuan came next, when a group of clique legislators refused to approve an emergency bill that would give the Executive Yuan more authority to manage crises. ${ }^{10}$ After observing these disputes, Chiang could no longer contain his anger:

Party members have become rude and unreasonable. In their minds they no longer care about the survival of the party and the state. I must set my mind on the task of rectifying the party so that it can survive. Without completely reforming the party, there will be no hope to save our nation. ${ }^{11}$

But as the crisis worsened, more former officials and party members backed away from radical political reform because they feared that the little power they still enjoyed might be transferred to other party members. ${ }^{12}$ Other things also prevented Chiang from launching party reform. In the spring of 1950 the Nationalist government confronted a difficult military choice: Chiang could use the offshore islands still under KMT control to launch attacks against mainland China but risk losing forces that could defend Taiwan; or he could strengthen Taiwan's defenses by withdrawing all Nationalist military forces back to Taiwan from the offshore islands along the coast of southeastern China.

Chiang appealed again for U.S. support for his anticommunist stand but still heard nothing from Washington. ${ }^{13}$ As invasion and death threatened the island, Chiang had to postpone party reform and hope for a miracle. ${ }^{14}$

When Chiang learned that civil war was breaking out on the Korean Peninsula, he realized that the winds of good fortune had finally blown his way. Two days after the Korean War began, on June 25, 1950, the United States sent

\footnotetext{
${ }^{9}$ K. C. Wu, Wu Guozhen Zhuan (The biography of K. C. Wu) (Taipei: Liberty Times, 1995), vol. 2, pp. $428-40$.

${ }^{10}$ Li Songlin, Jiang Jieshi de Taiwan Shidai (Chiang Kai-shek and Taiwan) (Taipei: Fengyun Shidai, 1993), pp. 108-12; Dashi Changbian, vol. 9, p. 167.

${ }^{11}$ Ibid., p. 169.

12 Ibid., pp. 168-69, 171-72, 180.

${ }^{13}$ Robert Accinelli, Crisis and Commitment: United States Policy toward Taiwan, 1950-1955 (Chapel Hill: University of North Carolina Press, 1996), pp. 3-28.
}

${ }^{14}$ Dashi Changbian, vol. 9, p. 145. 


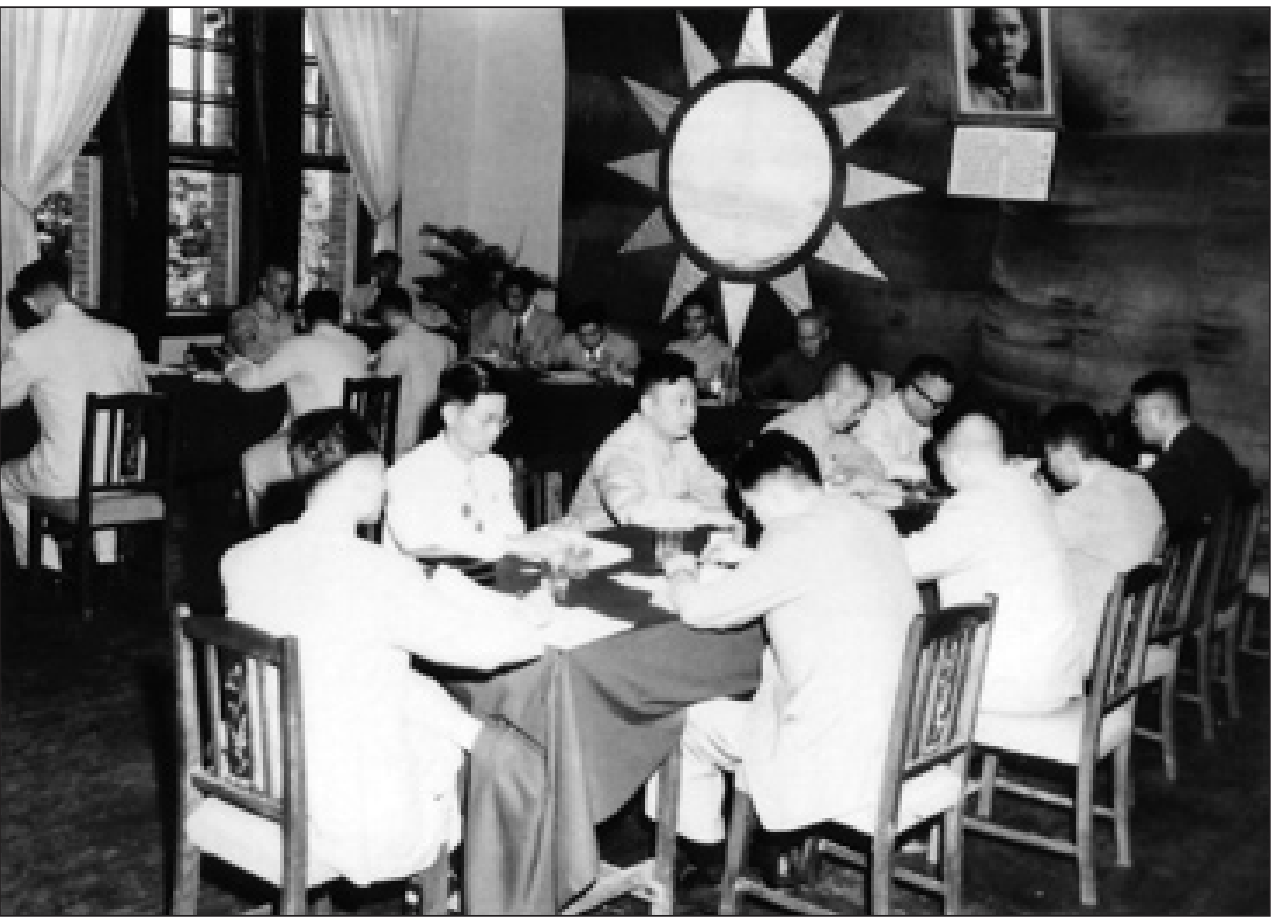

In August 1950, the KMT held its first Central Reform Committee meeting to launch the party's reforms. (1950)

the Seventh Fleet to the Taiwan Strait to protect the island from a Communist invasion and prevent Nationalist forces from attacking mainland China. As the Communist take-over of Taiwan had been repulsed, Chiang was now confident that he could initiate a genuine reorganization of the KMT.

On August 5, 1950, Chiang designated the Central Reform Committee (CRC) to be the party's core leadership for planning and acting. His handpicked sixteen CRC members were relatively young (average age forty-seven) and well educated (all had college degrees or the equivalent, nine had studied abroad, and two had Ph.D.s from U.S. universities). ${ }^{15}$ This new leadership made Chiang believe he could now trust his inner circle. Thus he was ready to create a devoted political party that would be an instrument for political change.

\footnotetext{
${ }^{15}$ The sixteen members were Chen Cheng, Zhang Qiyun, Zhang Daofan, Gu Zhenggang, Zhen Yanfen, Chen Xueping, Hu Jianzhong, Yuan Shouqian, Cui Shuqin, Gu Fengxiang, Zeng Shubai, Jiang Jingguo (Chiang Ching-kuo), Xiao Zicheng, Shen Changhuan, Guo Zheng, and Lian Zhendong. See Gaizao (Reform), no. 1 (September 1, 1950): 19-25.
} 


\section{Building a Strong Party and Leadership}

THE NEW CRC HAD SIX GOALS. First, make the KMT a revolutionarydemocratic party; second, recruit peasants, workers, youth, intellectuals, and capitalists; third, adhere to democratic centralism; fourth, establish the work team (xiaozu) as the basic organizational unit; fifth, maintain high standards of leadership and obey the party's decisions; and, sixth, adopt Sun Yat-sen's Three Principles of the People as the KMT's ideology. ${ }^{16}$ All CRC members took an oath to fulfill the party's ultimate goals - annihilate the Communists and recover the Chinese mainland. ${ }^{17}$

New strategic concerns were also discussed. Party factionalism must be abolished and members' loyalty established. Unlike the old mainland party, the party's new core had only 16 members; the old Central Standing Committee and Central Executive Committee had 50 and 223 members, respectively. The CRC's core members also served as the party's executive and policy planning body.

In the meantime, Chiang isolated all his opponents and established the Central Advisory Committee, an honorary body directly under his control but without power. The CRC then assigned the members of the Chen brothers' Central Club, the Guangxi clique, and the Political Study Group (Zhengxuexi) to the Advisory Committee, thus honoring but also marginalizing the party veterans, preventing them from splitting the party's new leadership. ${ }^{18}$

Pleased that a reinvigorated KMT was becoming a reality, Chiang, in his diary entry of July 26, 1951, underscored this change:

The Resolution on Reforming the Party has now been adopted, and the new members of the Central Reform Committee have been announced. It is indeed a gigantic event in the history of our revolution. It will also be the last step to resuscitate the dying KMT. Once we are able to pass this critical test, the obstacles blocking our future revolutionary actions will be trivial. ${ }^{19}$

\footnotetext{
${ }^{16}$ CRCA, 6.4-1, reel 2, KMT Central Reform Committee, "Outline of the Reform Program of the Party," July 1950 (n.d.).

${ }^{17}$ CRCA, 6.4-2, reel 12, Chiang Kai-shek's instruction at the 420th meeting of the CRC, October $9,1952$.

${ }^{18}$ Li Yunhan, Zhongguo Guomindang Shishu (A historical narrative of the KMT) (Taipei: KMT Party Historical Commission, 1994), vol. 4, pp. 74-80; Dickson, "Lessons of Defeat," p. 67.

${ }^{19}$ Dashi Changbian, vol. 9, p. 215.
} 
Significantly, the new personnel structure consolidated Chiang Kai-shek and Premier Chen Cheng as the party's top leaders. The paramount leader, Chiang, was followed by the sixteen-member CRC, with Chen Cheng holding the first position. A twenty-five-person advisory group, a secretary-general (Zhang Qiyun), and deputy appointed from its ranks assisted the CRC. This new structure was in charge of thirteen new agencies: a secretariat, seven committees to study and carry out specific reform duties, and five committees that trained party cadres, recorded party reforms, managed party affairs, edited party history, and were in charge of planning. ${ }^{20}$

When the CRC began meeting on a weekly basis, Chiang Kai-shek asked that particular attention be paid to the ideological and disciplinary instruction of party members. Earlier, on October 16, 1949, Chiang had established a party cadres' school, the Academy for the Study of Carrying out Revolution (Geming Shijian Yanjiuyuan) on Yanming Mountain near Taipei. He wanted all party cadres to be endowed with the same revolutionary consciousness that he had and to be strongly loyal to the party leadership. In the following thirty months, the academy graduated, from four- to six-week training cycles, more than three thousand cadre leaders, all of whom had come to share Chiang's way of thinking.

Chiang urged all the students to undergo "inner" changes by purging themselves of "selfishness, corruption, and bureaucracy." ${ }^{21}$ The top leaders, he said, should purify their thinking and be ready to lay down their lives for Sun Yat-sen's Three Principles of the People. The academy ran smoothly in the years that followed, for only those who had participated in Chiang's training course were eligible for high positions in the party or the government or both.

In retrospect, the 1950-52 party reform was probably Chiang Kai-shek's greatest achievement as leader of the KMT. The reform campaign produced a new core of leaders who agreed with Chiang on the party's long-term economic and political goals and were dedicated to achieving them. Chiang Kai-shek had now consolidated his power and authority; no one challenged him after the reforms had been instituted. The CRC members, experienced and loyal to Chiang, were given the power to implement party policies. Further, Chiang's young, trained leaders were not free of the negative influence of those party veterans

\footnotetext{
${ }^{20}$ CRCA, 6.4-2, reel 1, minutes of the 1st meeting of the CRC, August 6, 1950.

${ }^{21}$ Chao and Myers, First Chinese Democracy, pp. 24-25.
} 
who had served on the mainland. These academy graduates gave the KMT the organizational strength it had lacked. ${ }^{22}$

Chiang Kai-shek and his CRC members knew that long-term success depended on the party's leadership having the authority to operate on its own without fear of partisan reprisals. ${ }^{23}$ Chiang's young, well-educated technocrats were to establish the groundwork for others to follow and take their place in the party as well as in the government. Finally, the new KMT leaders' and members' shared ideology promoted the liberal economic and political reforms of the 1950s. The party pushed not only for incremental changes but for broadening the KMT's social base, which would give rise to a large middle class in later decades. $^{24}$

\section{Expanding the Party's Social Foundation}

HAVING ORGANIZED A COHESIVE, LOYAL PARTY, Chiang Kai-shek wanted to extend its influence deep into Taiwan society so as to broaden its social base. One way in which to do that was to select new members from different social strata and groups. Shortly after the CRC was established, its leaders approved reregistering members who had lost contact with the party during the civil war (1945-49). During reregistration, more than twenty thousand members returned to the party and then helped the CRC recruit more Taiwanese. ${ }^{25}$

During the civil war, China's intellectuals and students had abandoned the KMT. To win back their support and confidence, the various party branch headquarters and cells were mandated to recruit new members, especially students and teachers. By early 1952, more than forty party branches were recruiting intellectuals and educated youth, with more than 40 percent of Taiwan province's party members' having at least a high school or college education. ${ }^{26}$ More than 130 district branches were also recruiting talented party members.

\footnotetext{
${ }^{22}$ Peter Chen-main Wang, "A Bastion Created, a Regime Reformed, an Economy Reengineered, 1949-1970," in Murray A. Rubinstein, ed., Taiwan: A New History (New York: M. E. Sharpe, 1999), pp. 328-32.

${ }^{23}$ CRCA, 6.4-2, reel 1, Resolution on the Reforming of our Party, July 18, 1950.

${ }^{24}$ Hood, The Kuomintang and the Democratization of Taiwan, pp. 28-29, 51.

${ }^{25}$ CRCA, 6.4-2, reel 5, Annual report of the Central Reform Committee for the fiscal year 1951 (Taipei, August 1951), p. 4.

${ }^{26}$ Ibid., pp. 12-13; Gaizao, no. 36 (February 16, 1962): 3-5.
} 
B REAKING WITH THE PAST
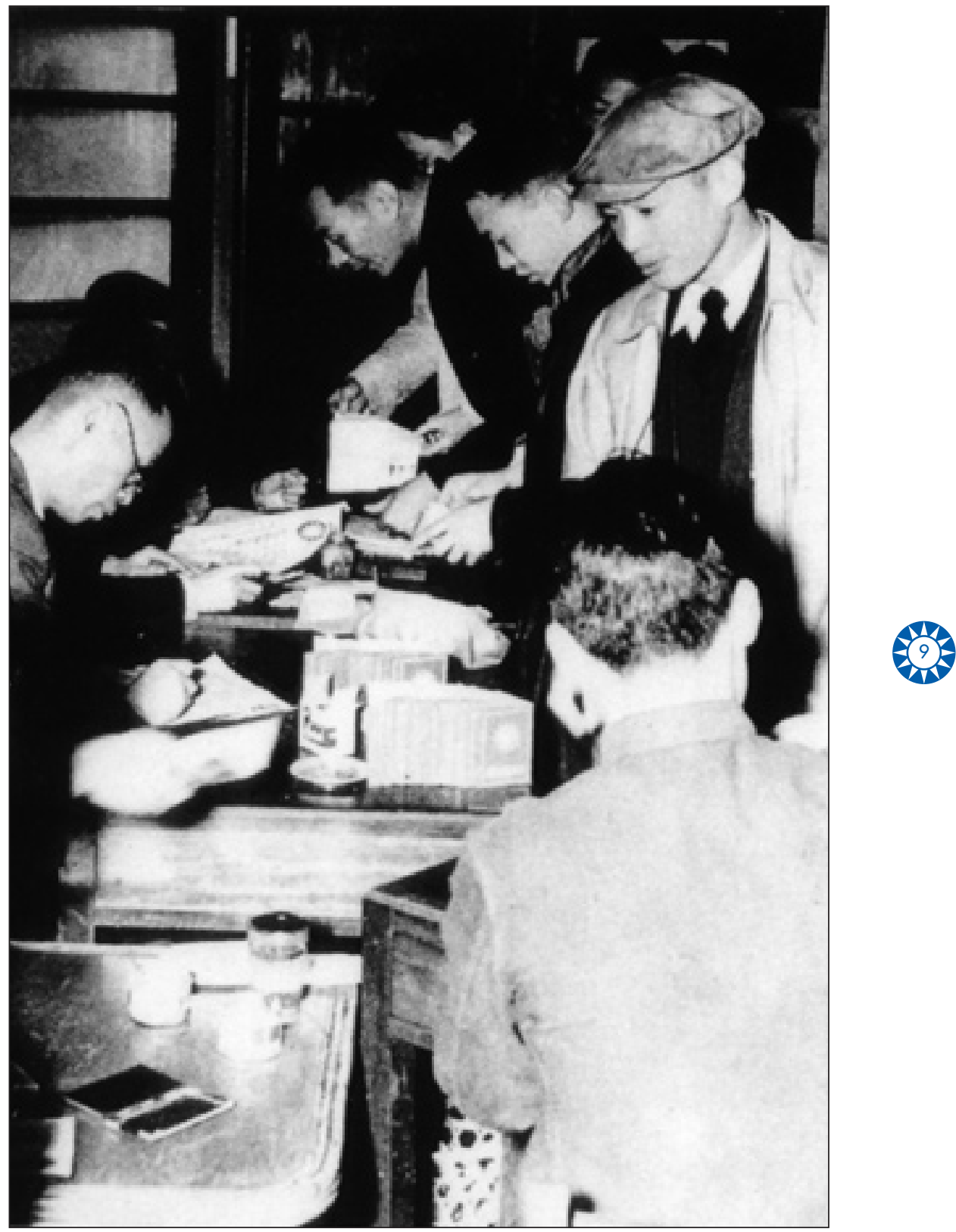

In the fall of 1950, the Central Reform Committee reregistered former party members and recruited new ones. (1950) 
The CRC assigned one committee to manage party recruitment. New rules and regulations were promulgated to ensure high-quality membership. For instance, new members had to demonstrate loyalty to the KMT party, understand what the party represented, obey party principles, and perform services for the party. They also had to pay dues. ${ }^{27}$ In return, the CRC promised to pay attention to society's needs, thus helping the CRC define a clear political agenda and give a purpose to the KMT, something that had been missing from the mainland KMT. ${ }^{28}$ The CRC also wanted to recruit farmers and workers, in addition to intellectuals. It wanted party branches in communities with lots of young people who could recommend possible recruits. ${ }^{29}$ Party policy also targeted ways to improve ordinary people's living conditions. Having new party branches made up of people of similar social status was a tactic that improved relations with workers, business leaders, farmers, intellectuals, and other interested individuals. ${ }^{30}$ Although the KMT did not advocate creating a "democratic" Taiwan, its members continued to discuss how some democratic ideals could help recruit new members and clarify national goals. ${ }^{31}$

With the new party branches promoting the various vocational groups, the KMT was able slowly to extend its control and influence into Taiwan's villages. Thus, when the Seventh Party Congress convened in October 1952, KMT membership had reached nearly 282,000, compared to the 50,000 members who had fled to Taiwan. More significant, more than half the party members were Taiwanese. ${ }^{32}$ By the late 1960s, this number had risen to nearly one million.

As the CRC recruited, it also created a cadre system that deepened its political and ideological control at every level of the state administration. On

\footnotetext{
${ }^{27}$ CRCA, 6.4-2, reel 3, minutes of the 109th CRC meeting, April 5, 1951; 6.4-2, reel 5, Regulations adopted in the 171st CRC meeting, July 16, 1951.

${ }^{28}$ CRCA, 6.4-2, reel 1, minutes of the 36th CRC meeting, October 12, 1950.

${ }^{29}$ CRCA, 6.4-2, reel 5, "Annual report of the Central Reform Committee for the fiscal year 1951," August 1951 (n.d.), pp. 18-21.

${ }^{30}$ CRCA, 6.4-2, reel 2, working guidelines for youth, labors, farmers and social service, in the minutes of the 78th and the 79th CRC meeting, dated January 29 and 31, 1951.

${ }^{31}$ Cao Junhan, "Suzao Zhongguo Guomindang wei Gonggong Zhengce Zhengdang" (Molding the KMT into a responsive public party), in Yang Taishun ed., Zhengdang Zhengzhi yu Taiwan Minzhuhua (Party politics and Taiwan's democratization) (Taipei: Democracy Foundation, 1991), pp. 57-59.

${ }^{32}$ See: Zhongguo Guomindang Gaizao Qijian Gongzuo Gaikuang Tuka Ji (A pictorial survey of general working conditions for the KMT during the reform period) (Taipei, 1953), p. 34. According to the CRC, by August 1952 there were 115,037 members registered at the KMT Taiwan Provincial Headquarters. See Dangwu Baogao, vol. 2, pp. 5-6.
} 


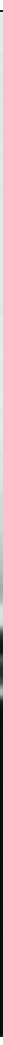

As the reforms began, branch offices of the Central Reform Committee sprang up in the cities and counties of Taiwan.

(1950)

the mainland, the KMT had made the party branch ( $q u$ fenbu) the basic organizing unit and the work team (xiaozu) to train party members in how to read reports and discuss current events. When reform began in Taiwan, the CRC made its work teams responsible for enforcing party policies and informing members how to behave. They were also to produce propaganda, prevent communist infiltration, and recruit new party members after investigating their backgrounds, as well as to hold regular meetings to discuss party strategy. ${ }^{33}$ The new party, then, behaved very differently from the way it had before 1949, with its work teams having new managerial and training responsibilities.

${ }^{33}$ CRCA, 6.4-2, reel 1, minutes of the 30th CRC meeting, September 29, 1950; 6.4-2, reel 4, minutes of the 143rd CRC meeting, May 30, 1951. 
Because national security was still a primary concern for Chiang Kai-shek, he insisted on tightening the grip of party organizations and disciplining work teams to prevent Communists from infiltrating Taiwan. Chiang especially feared that the Communists would enter Taiwan from the sea by recruiting impoverished Taiwanese fishermen to aid them in their efforts. His instructions at the eighty-second meeting of the CRC reveal that concern:

Fishermen are particularly important for consolidating our regime and for our military to recover the Chinese mainland. We should pay close attention to strengthening their organization and training, and help improve their living standards so that they will not be manipulated by Communist bandits. ${ }^{34}$

According to the KMT's new rules, all party members had to join a work team and attend its meetings so that the party leadership could discover who was loyal and active. Trusted party members monitored the other members. According to one report, the KMT's Taiwan provincial party headquarters in the summer of 1952 had at least thirty thousand work-team units in the field, each containing at least nine members who worked in various state agencies, areas of Taiwan, and occupations. ${ }^{35}$ Work teams were also to transmit party instructions to the people and elicit their support. Gradually, the party expanded its influence in society and in the state.

Investigating Taiwan society (shehui diaocha) became another new task for the work team. During the two reform years, all party work teams were to conduct social surveys covering how party members executed orders and how the people responded to party demands. Work teams also were to collect evidence of illegal or communist activities, ${ }^{36}$ as well as obtain information about area notables. The party then used those lists to identify people the party should keep an eye on. ${ }^{37}$ Although budget and manpower limitations prevented work teams from making in-depth investigations, the surveys did provide information to help with KMT state-building efforts and to control the population. Meanwhile,

\footnotetext{
${ }^{34}$ CRCA, 6.4-2, reel 2, minutes of the 82nd CRC meeting, February 8, 1951.

${ }^{35}$ Gaizao, no. 47/48 (August 1, 1952): 42-43.

${ }^{36}$ CRCA, 6.4-2, reel 2, minutes of the 58th CRC meeting, December 6, 1950.

${ }^{37}$ CRCA, 6.4-2, reel 4, minutes of the 168th CRC meeting, July 9, 1951; Gaizao, no. 19 (June 1, 1951): 65 .
} 
the party was helping its members learn how to interpret and explain domestic and international issues. ${ }^{38}$

Chiang Kai-shek, however, was still concerned about how to preserve party control and, at the same time, enlist talented people to join the party and the government. That problem had never been solved in mainland China. In a CRC meeting held on April 19, 1951, Chiang expressed his worries:

I deeply feel that our lack of talented people was the main reason for our failure to accomplish our revolutionary tasks and build a solid organization. It is now clear that the success of our revolutionary activities heavily depends on our ability to recruit more talented people to serve our party. I profoundly hope that our party comrades will be able to recommend talented individuals to recruit and train properly. $^{39}$

\section{Local-level Political Reforms}

ONE IMPORTANT KMT STRATEGY was promoting limited, local-level political reforms to strengthen the party's legitimacy with the Taiwanese people. Under the flexible "revolutionary democracy" guideline, Chiang approved the rule of democratic centralism so as to broaden the party's social base. To legitimate the Republic of China (ROC) as the central government for all China, Taiwan's Nationalist government needed elected representatives for all China. Thus, in 1947 more than one thousand mainlanders in Nanking were elected by the Chinese people as members of the National Assembly, Legislative Yuan, and Control Yuan. After coming to Taiwan, those representatives were permitted to hold their seats until the next ROC election could be held on the mainland, thus legitimizing the ROC's control of Taiwan. ${ }^{40}$ In this new political environment the reformed KMT and the ROC government were able to project their new power.

\footnotetext{
${ }^{38}$ Dickson, "Lessons of Defeat," pp. 78-79.

${ }^{39}$ CRCA, 6.4-2, reel 3, minutes of the 118th meeting of the CRC, April 19, 1951.

${ }^{40}$ Denny Roy, Taiwan: A Political History (Ithaca: Cornell University Press, 2003), pp. 84-85.
} 
During the 1950-52 reform era, the CRC's top leaders adhered to the ROC civil code and martial law. ${ }^{41}$ Chiang Kai-shek believed that, in this authoritarian polity, local elections could promote Taiwan's eventual democracy. Shortly after the first county and city elections in early 1951, Chiang explained to CRC members how a competitive electoral system could help the KMT and the ROC:

The recent county and city council elections were a first step toward establishing a complete democratic system.... For developing our nation and society, it is indeed a comforting message that the success of all those elected is not the result of partisan manipulations, but through fair and clean competition....The results of the election also provided the party with a good opportunity to be introspective. This time, two of our nominees lost in their campaigns. But without this failure, our fellow comrades probably would still retain their old conceited attitudes, as was the case in the mainland. They may still believe that, having the party's usual organization and propaganda support, our party's social base will be easily consolidated....Although our two nominees lost their battles, it is comforting that a genuine democratic system has been established. ${ }^{42}$

Taiwan's local elections-open and competitive as they were-did not always convince people that the KMT would never intervene in such elections. Having so many local elections in a year, however, did convince many voters that the KMT wanted to foster political pluralism, although party leaders believed that political tutelage was necessary to teach voters how democracy should work. By so doing the leaders hoped to broaden their influence while only slowly allowing opposition politicians to compete.

In January 1951, the first elections for county and city council seats were held. In April, other elections followed for county and municipal offices. In December, the Taiwan Provisional Provincial Assembly was organized, with its members having been appointed by county and municipal assemblies. ${ }^{43}$

\footnotetext{
${ }^{41}$ CRCA, 6.4-2, reel 7, "General guidelines for national mobilization," in minutes of the 293rd CRC meeting, February 21, 1951.

${ }^{42}$ Dashi Changbian, vol.10, pp. 6-8.

${ }^{43}$ Chen Yangde, Taiwan Difang Minxuan Lingdao Renwu zhi Biandong (Changes in locally elected leaders) (Taipei: Siji chubanshe, 1981), pp. 120-25.
} 


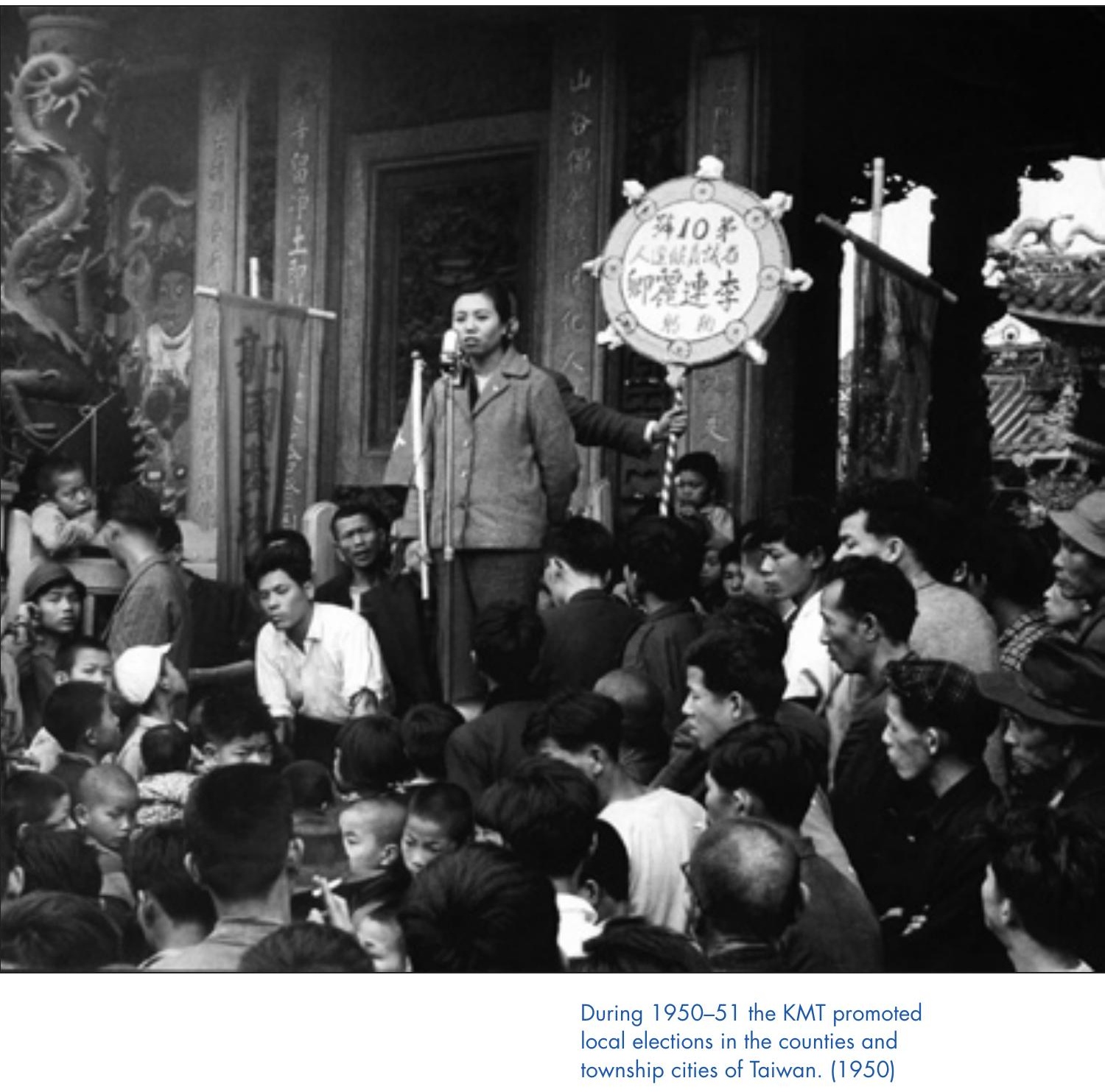




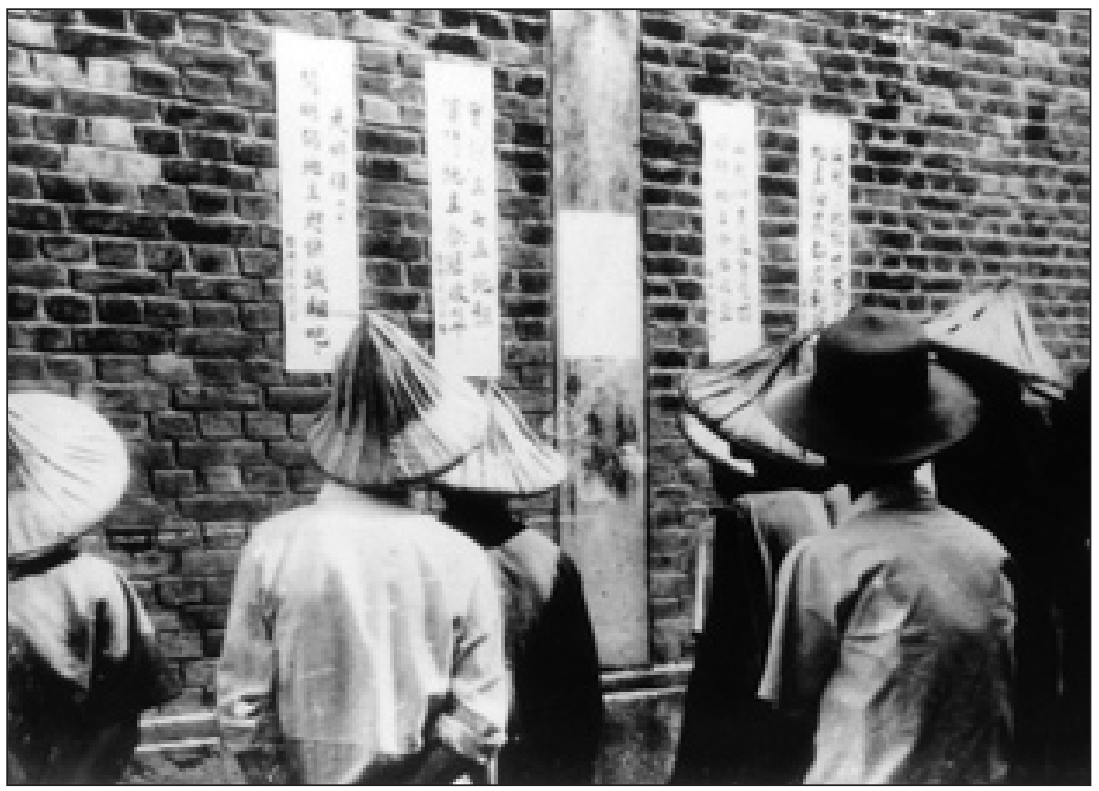

Taiwanese farmers learning from government posters about the 37.5 percent ceiling on rents and farm land redistribution.

Through martial law and the control of local election rules, the KMT won most of those local elections but claimed that free elections had been held.

In the early 1950s, the party's nomination system strengthened its control. Although a few local notables had great support in their districts, the KMT still dominated by virtue of its nomination system, which almost guaranteed that KMT candidates would be elected. The elections did, however, encourage local elites to join the party, win elected office, and then enjoy the benefits of those elected offices. ${ }^{44}$

As local elections progressed in the early 1950s, the KMT was also recruiting loyal, local followers to add to its growing power, which had both positive and negative results. On the one hand, local elections enabled the KMT to work closely with local Taiwanese elites and strengthen its claim of being a legitimate party representing the people. On the other hand, however, party involvement in local electoral affairs encouraged factionalism within the KMT. Although

${ }^{44}$ Hao Yumei, Guomindang Timing Zhidu zhi Yanjiu (A study of the KMT's nomination system) (Taipei: Zhengzhong shuju, 1981). 
local party branches tried to co-opt the new factional leaders, over time that became hard to do.

Local party branches' strategy to increase their control over local issues involved the following. ${ }^{45}$ Because faction leaders usually belonged to the KMT, the party could allocate limited elected posts among them. Although the party center continued to approve national policy and demanded unquestioned obedience to party directives, local leaders gained some power in managing local party affair. But those political actions also encouraged factionalism. ${ }^{46}$

Although conceding that more democracy was needed in the future, Chiang believed that enough liberalization had already occurred. Party leaders continued to emphasize that martial law was still necessary. Taiwan's limited democracy, guided by a new political party, thus mobilized popular support for the KMT. For the first time in its history, the KMT, learning from its mistakes, had organized a new polity.

\section{Promoting a Grand Vision: Toward A Prosperous Economy with Equity}

PARTY AND STATE REFORMS HAD IMPROVED the KMT'S organization, unified its leadership, broadened its social basis, and strengthened its legitimacy. Humiliated and disgraced because of losing the civil war, most KMT members had switched to agreeing with Chiang Kai-shek's grandiose vision. They realized their defeat could be an opportunity for self-examination and finally having a mission: namely, to strengthen and modernize the small part of China they still governed.

Incremental, but tangible, progress slowly elevated party prestige. Having learned how brutally the Communist Party was governing the mainland, more people began condemning Chinese communism as a failure. As the Taiwanese worked with the KMT, some even believed that recovering the mainland might be possible. ${ }^{47}$ Meanwhile, the KMT addressed itself to solving the land problem.

\footnotetext{
${ }^{45}$ CRCA, 6.4-2, reel 3, minutes of the 92nd CRC meeting, February 28, 1951; minutes of the 109th CRC meeting, April 5, 1951.

${ }^{46}$ Dickson, "Lessons of Defeat," pp. 74-75; Hood, The Kuomintang and the Democratization of Taiwan, pp. 33-34.

${ }^{47}$ Zhang Qiyun, Guomindang di Xinsheng (The rebirth of the KMT) (Taipei: Chinese Cultural Service, 1952), pp. 63-64.
} 
The KMT's land redistribution in 1949-53 brought a surge of economic and social progress to the island's population without the bloodshed reported by so many refugees from the mainland. Chen Cheng believed, correctly as it turns out, that land reform would reduce support for communism. As land reform spread, the confidence of Chen and other CRC leaders in their policy increased as they avoided the mistakes they had made on the mainland. ${ }^{48}$

Chen Cheng planned three phases of reform-reducing rents in 1949, selling public land in 1951, and transferring land ownership to poor tenant farmers in 1953 - which he began by calling for a 37.5 percent ceiling on rents. In 1951, a CRC resolution offered one-fifth of the island's arable land for sale to tenant farmers for a price well below that of the market. Buyers then had ten years to buy their land by means of produce rather than cash with no interest. ${ }^{49}$ Land assessment and agricultural extension offices were established by the government's land bureau, which oversaw the start-up of farmers' and irrigation associations, quasi-governmental organs that helped local farmers follow government guidelines. More than 150,000 tenant farm families bought land under the program. ${ }^{50}$ If the average household had seven persons, more than one million people (out of a population of six million) acquired additional land.

Finally, the 1953 Land to the Tiller Act enabled landlords to still own a limited amount of land. They were compensated with land bonds and stock shares from four privatized, government-owned enterprises: Taiwan Cement Corporation, Taiwan Pulp and Paper Corporation, Taiwan Agriculture and Forestry Corporation, and Taiwan Industry and Mining Corporation. The former tenants purchased that land for 2.5 times the land's annual crop value. The privatized corporate assets financed the stocks and bonds with which the landowners were compensated. Meanwhile, the new landowners were eligible for loans that could be repaid, with no interest, in ten years. They also received funds so they could modernize their farms and irrigation operations. ${ }^{51}$ More than one million Taiwanese gained property rights under the land reform pro-

\footnotetext{
${ }^{48}$ Ching-yuan Lin, "Agriculture and Rural-Urban Migration: The 1949-53 Land Reform," in James C. Hsiung et al., eds., The Taiwan Experience 1950-1980 (New York: Praeger, 1981), pp. 138-41.

${ }^{49}$ CRCA, 6.4-2, reel 2, minutes of the 87th CRC meeting, February 19, 1951.

${ }^{50}$ John F. Copper, Taiwan: Nation-State or Province? (Boulder, Colo.: Westview Press, 1996), pp. 131-32.

${ }^{51}$ CRCA, 6.4-1, reel 1, "Current condition of the KMT," 1952, chapter 2.
} 
gram, and the income of farmers nearly doubled in the decade after $1949 .^{52}$ Because land reform had enabled many of Taiwan's farmers to get rich, they began throwing their support to the KMT.

In September 1950, as the land reform program was getting under way, the CRC decided to strengthen the national economy by designating the new, state-owned enterprises to take over mining, petroleum extraction and refinement, and steel production, as well as the production of electric power, sugar, fertilizer, cement, pulp, paper, and ships. In addition, the government operated monopolies that produced alcohol and tobacco, whereas forestry was managed by the provincial government, thus giving it a revenue source. ${ }^{53}$ Establishing such a large core of state-owned enterprises followed Sun Yat-sen's economic development model. ${ }^{54}$ Reforms after 1953, however, concentrated on promoting private enterprise, with a focus on institutional change.

The party thus used the economic power of the state to encourage the rise of a market economy. Although many directing Taiwan's economic policy planning, such as K.Y. Yin (Yin Zhongrong), were non-KMT members, Chiang Kai-shek and Chen Cheng allowed them to remain in their jobs in an effort to promote liberal economic reforms. The party also made it possible for young technocrats such as Yin to manage Taiwan's economic and financial affairs without political interference. Such tolerance showed the KMT's willingness to connect creativity with a free market economy. But although the KMT in its reform period still advocated "revolutionary democracy," it carefully selected only loyal Taiwanese for KMT membership. Meanwhile, the party softened its ideological demands and abandoned the idea of making Taiwan a launching pad for recovering the mainland. ${ }^{55}$

\footnotetext{
${ }^{52}$ F. A. Lumley, The Republic of China under Chiang Kai-shek: Taiwan Today (London: Barrie \& Jenkins, 1976), p. 69; Chen Cheng, Land Reform in Taiwan (Taipei: China Publishing Company, 1961), pp. 47-48.

${ }^{53}$ CRCA, 6.4-1, reel 1, CRC working report for the year 1950; Xu, Zhongguo Guomindang de Gaizao, pp. 138-42.

${ }^{54}$ CRCA, 6.4-2, reel 3, minutes of the 119th CRC meeting, April 19, 1951.

${ }^{55}$ Hood, The Kuomintang and the Democratization of Taiwan, pp. 32-33.
} 


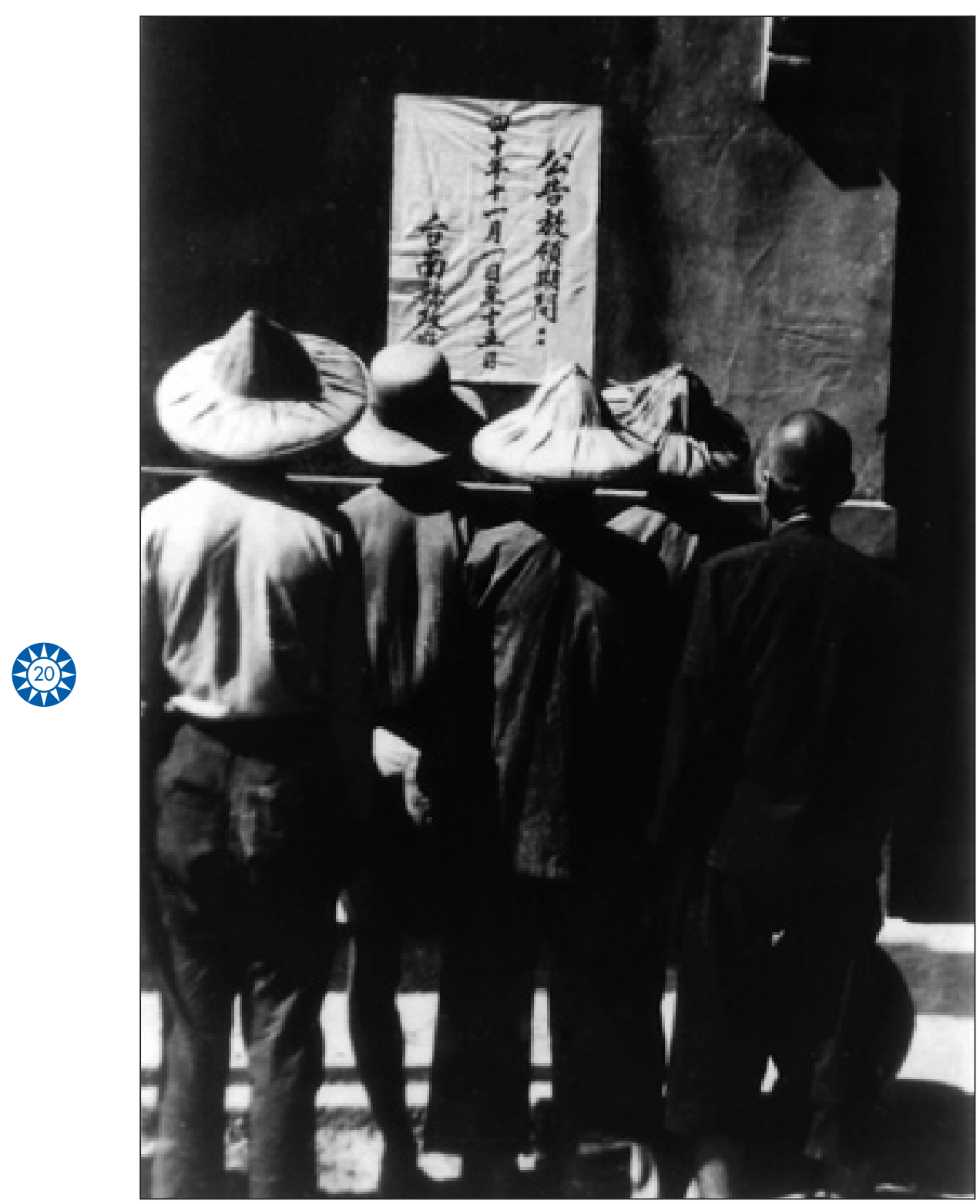

Farmers and landlords examine an announcement of the Redistribution of Public Lands Act. This law allowed the ROC government to redistribute public lands to Taiwan's poor farmers and tenants. (1951) 


\section{Concluding Remarks}

WHEN THE KMT CONVENED its Seventh National Congress in October 1952, the CRC's role was officially ended, with Chiang Kai-shek and Chen Cheng now leading the party. In the preceding two years, Chiang and the ROC government, together with the CRC, had built a new political regime. The KMT encouraged citizens to join with party members to achieve the national goals supported by the party and state. Although the CRC did not fulfill the KMT's grand goal-recovering the Chinese mainland-it had transformed the defeated and demoralized KMT organization into a new ruling party that clearly defined citizen's rights and obligations. We can summarize the reinvigorated party's achievements as follows:

First, the CRC had established a party leadership of young, creative executive managers by reorganizing the party's structure and eliminating the old factions. Second, the CRC had given the KMT an identity and purpose. Third, the CRC had set up a cadre school to train party members in party policies and principles. Fourth, the new KMT had expanded the party's social support, thus solving the "penetration crisis." ${ }^{56}$ Last, but not least, local elections and economic reforms had begun restructuring the society, economy, and polity. When taken together, those achievements enabled the party to recruit loyal members, establish party discipline, and share a common ideological vision.

The KMT could now exert its influence on the government and society and interact with the people of Taiwan. The party had never held such power or imposed such influence on the mainland. To revitalize itself in a new environment, the KMT introduced new rules and regulations that strengthened the party's institutions. By paying attention to party organization, institutions, and mission, Chiang Kai-shek had consolidated more power to the KMT than ever before.

In the next two decades, the KMT governed through enlightened authoritarianism. By the 1970s, however, the party, responding to new political opposition, began loosening its control. Democratic reforms were introduced in the late 1980s, followed by further reform in the early 1990s.

The KMT's overall achievements could never have been anticipated in 1949. Having miserably failed before 1949, even its Taiwanese supporters had little confidence the old party could be reformed. But the KMT had learned its lesson, and, after two years of sweeping reforms, its confidence increased.

\footnotetext{
${ }^{56}$ Gabriel A. Almond and G. B. Powell, Comparative Politics: A Developmental Approach (Boston: Vakilis, 1966), p. 308.
} 
Without the iron will of Chiang Kai-shek and his handpicked CRC members in the early 1950s, the party might well have splintered and collapsed, disappearing into the dustbin of history. 


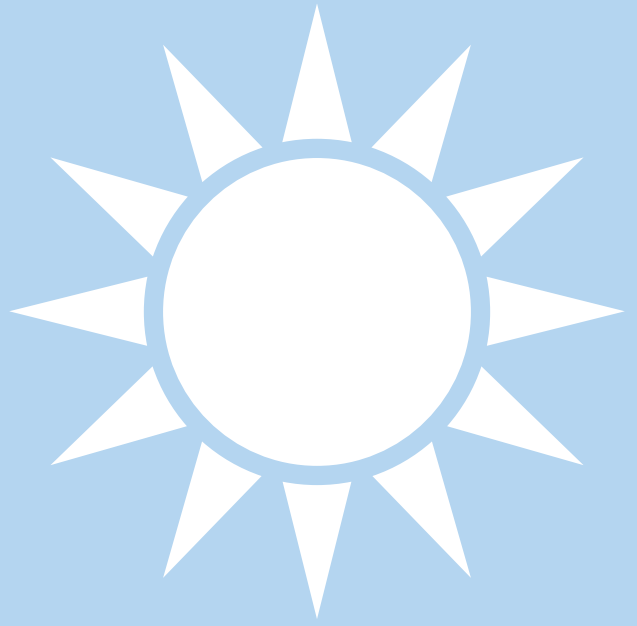



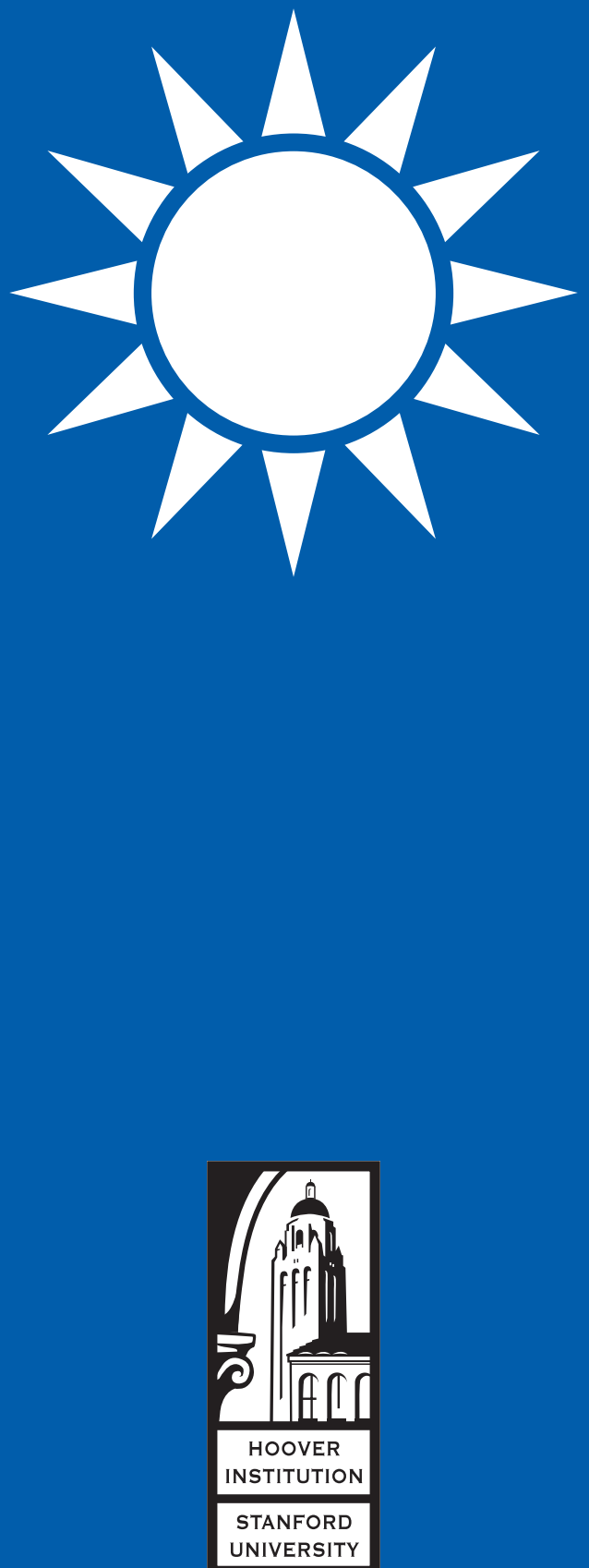